\title{
The Function of Code-Switching in Selma Dabbagh's Out of It
}

\author{
Bilal Tawfiq Hamamra, Salsabil Qararia *
}

Department of English, An-Najah National University, Nablus, Palestine

Corresponding Author: Bilal Tawfiq Hamamra, E-mail: bilalhamamra@najah.edu

\section{ARTICLE INFO}

Article history

Received: December 19, 2017

Accepted: March 10, 2018

Published: April 30, 2018

Volume: 9 Issue: 2

Advance access: March 2018

Conflicts of interest: None

Funding: None

Key words:

Selma Dabbagh,

Out of It,

Palestinian Culture,

Code-Switching,

Cultural and Textual Hybridity, Types

and Categories of Code-Switching

\begin{abstract}
Bilingualism and biculturalism have a very immediate impact on the make-up of literary works of bilingual and bicultural authors with immediate linguistic traces of bilingual and bicultural mosaic of textual creation. Code-switching is a linguistic and cultural practice used by bilinguals in writing and speaking. This article examines the linguistic and cultural phenomenon of code-switching employed in Selma Dabbagh's novel Out of It (2011). We argue that Dabbagh uses code-switching from English into Arabic so as to address the concerns of Palestinians and maintain her Palestinian belonging. At the very beginning, we explain what is meant by code-switching and briefly elucidate the reasons why bilingual authors use this technique. Thereafter, we shed light on the author's background and expound the different types of code-switching she employs in Out of It. The upshot of this article clears up cultural and textual hybridity as the product of the application of code-switching.
\end{abstract}

\section{INTRODUCTION}

Code-switching is a linguistic technique that refers to the act of shifting between two languages or two dialects while speaking or writing. Monica (1988) states that code-switching is "the use of more than one language in the course of a communicative episode" (p. 1). This phenomenon is employed deliberately or consciously by bilinguals or multilinguals to create textual and cultural hybridity. Martin (2005) argues that:

For multilingual authors, switching between two or more languages is not an arbitrary act, nor is it simply an attempt to mimic the speech of their communities; code-switching results from a conscious decision to create a desired effect and to promote the validity of authors' heritage language (pp. 403-404).

Speakers or writers of more than one language have the competence to code-switch between languages in order to transfer a specific message; "juxtaposing two codes can have a signaling value of its own" (Auer, 1995, p. 119). Ervin-Tripp (1964) argues that the code or "variety" consists of a "systematic set of linguistic signals which co-occur in defining settings. For spoken languages, alternative codes may be vernaculars or superposed" (p.90). Dabbagh uses vernacular codes such as bisser (it happens) and Aanjad?(really?) rather than using standard codes (yumkin an yahduth: it happens, and haqqan?: really?) respectively because she, particularly, depicts the Palestinian culture in the novel.

Code-switching is used by bilinguals so as to compensate for insufficiency existing in a language. Crystal (1987) posits that "a speaker may not be able to express him/herself in one language so switches to the other to compensate for the deficiency" (cited in Skiba, 1997, p. 1). This could be the result of cultural diversity where a concept or an object may not be found in the other culture. For example, тиеzzin or muethen (one who calls for prayer from the minaret of the mosque) is a religious concept that is absent in non-Islamic and non-Arabic speaking countries.

In their discourse or writing, people code-switch in or-der to provoke some literary, social, and cultural effects. For example, Dabbagh, in her novel, uses the term Ya hajji (a pilgrim) or Ammo (paternal uncle) when addressing an el-derly person for the sake of showing respect. Furthermore, the author uses the word hasad to demonstrate that Arabs believe highly in the evil eye and its effects. Many Palestinians, especially those who are living in rural areas and ruled by stagnant traditions, believe in the power of the evil eye in that a man or a woman can cause harm to the object of 
their gazes due to envy. The exploitation of code-switching, as Skiba (1997) argues, expresses solidarity with a distinct social group; "the socio-linguistic benefits have also been identified as a means of communicating solidarity, or affiliation to a particular social group" (p. 2). Bill Ashcroft, Gareth Griffiths and Helen Tiffin explain that postcolonial authors use codeswitching for "inscribing alterity" and "in-stalling cultural distinctiveness in the text" (2005, p. 71). James O. Omole (1998) discusses code-switching as a situation "where the need to reach the widest possible readership conflicts with the wish to present the exact experience and create the same linguistic effects as in the other language" (p. 60). Within the context of Out of It, code-switching is inclusive for Palestinians who are privy to the meanings of the cultural expressions employed throughout the novel, and exclusive to the English audience who requires explanations to understand these expressions. By infusion the novel with code-switching, Dabbagh lays claim to Arabic and resist the dominance of English, contributing to the emergence of a linguistically and culturally hybrid text. Furthermore, her use of code-switching emanates from her commitment to the Palestinian cultural identity and cause despite the fact that she was born and grew up in Scotland.

This article examines the various types of codes in the Palestinian-British writer Selma Dabbagh's novel Out of It. Throughout the novel, Dabbagh switches from italicized to unitalicized words which give readers the sense that the characters are code-switching between Arabic and English. Throughout the novel, words which are not italicized are those of English while the italicized ones are spoken and written in Arabic. The Arabic explanation, translation or gloss placed in opposition to the English words might seem repetitive. However, code-switching enriches Out of It as a literary text from a cultural and stylistic points of view.

Selma Dabbagh (1970-) is a Palestinian British author who was born in Scotland. Her use of English rather than Arabic as the language of writing stems from the fact that she was born in Scotland and she studied in academic institutions dominated by English. While she has never lived in Pales-tine, she identifies as "British-Palestinian". Before she started writing fiction in her thirties, Selma worked as a human rights activist in London, the West Bank and Cairo. She was a final-ist twice for the Fish Short Story Prize and was nominated for the 2005 David T. K. Wong Award. Her short fiction shone in New Writing 15 (2007) and Qissat: Short Stories by Palestin-ian Women (2006). Dabbagh's novel, Out of It, which was set between Gaza, London and the Gulf, was published in 2011. In 2013, Selma was one of the five international writers to be awarded a grant by the British Council to support the writing of her next novel (British Council, 2017). Dabbagh occupies, to use Homi Bhabha's words, "a third space [...] where the negotiation of incommensurable differences creates tension peculiar to borderline exercise" (1994, p. 312.). Bhabha(1994) invites readers to consider how this space "may open the way to conceptualizing an international culture, based not on the exoticism of multiculturalism or the diversity of cultures, but on the inscription and articulation of culture's hybridity" ( $p$. 56 , italics in original). As we pointed out, even though she was not born and did not grow up in Palestine, Dabbagh is an advocate of Palestinian cause and culture. In an interview with Moore (2015), Dabbagh states that:

My motivations for writing about Palestine/the Middle

East started out as a desire, inspired partly by my

legal/ political background and partly by the works of Edward Said and Ahdaf Soueif, to express in a fictive form, using the English language, the Palestinian situation as I understand it(p. 330).

Dabbagh is influenced by Said's and Soueif's writings; Dabbagh's Out of It resonates with Said's Out of Place (1999). Her use of code switching is a linguistic and cultural phenomenon that the Egyptian-British author Soueif employs in her literary works. As a PalestinianBritish author, Dabbagh riddles her novel with a heritage identifiably linked to Palestinian culture which is not her own.

Dabbagh's Out of It centers on the struggles of Pales-tinian characters who move between Gaza, Britain and the Gulf and it engages in a cross-cultural dialogue that revolves around socio-political themes such as work, exile, study, love and friendship. Dabbagh's Out of It depicts the lives of the twins Rashid and Iman as they try to find places for themselves in the midst of the Israeli occupation; these two young Palestinians are trying to find a way out of Gaza. Dabbagh says that her passion for writing was driven by her love of books. She said that she decided to create "Palestinian characters who are not stereotypical, who are full of energy and vibrancy and desire for change" (2012). The events of the novel revolve around Rashid's desire to leave Gaza and go to London to study. His dream of winning a scholarship came true and now it is his chance to get "Out of It", out of Gaza. His sister, Iman, was shocked by the death of her friend. She witnesses a dreadful bombing, venerating a glamorously tragic leader in an eminent political party. The other character is Sabri, their older brother, who lost his wife, children and his legs in the war on Gaza. These characters end up in London. Code switching in Out of It is, therefore, a major outcome of languages in contact.

\section{Categories of Code-switching:}

Dabbagh employs code-switching so as to create predominantly English novel infused with Arabic culture-bound expressions which are crucial to the overall significance of the novel. Dabbagh asserts that "it was based on a gut feeling that the sentence sounded better with some Arabic in it. I felt it also gave more of a flavour of place" (personal communication, February 2, 2018). Dabbagh includes culture-bound expressions immediately followed by an English translation so as to facilitate their accessibility for monolingual English readers. Dabbagh states that "I put the word in English afterwards to help readers with no knowledge of Arabic (most of my readers)" (personal communication, February 2, 2018). Thus, Arabic exists in essence within the phrase though it is in English. Palestinian culture is a guest/ghost/host to the English culture and text. In doing so, the author shows her audience that two cultures can exist in one individual that one does not have to preclude the other. In some places, Dabbagh translates some codes, and in other contexts, she leaves other codes untranslated. For example, codes like jiddo, mukhtar, 
Ibn Shaheed, and batal are demonstrated, whilst words such as maamoul, keffiyeh, dabka, and mandil are not translated. As a result of the interaction between the English language and the Palestinian culture, language has been foreignised to the English readers. By leaving the words un-translated, Dabbagh conveys a sense of cultural distinctiveness, high-lighting the difference between British and Palestinian cul-tures. She expects her readers to work a bit harder to guess the meaning from the context, moving Western audience to Arab and Palestinian culture. By this course of action, Dab-bagh forces her readers to search not only to know the literal meaning of a word but also to get to know the Palestinian culture closely. The way that the author chooses to italicize these Arabic culture-bound expressions emphasizes the difference of the language and the difference of the people who speak it. This novel, accordingly, is congested with switched codes in its various chapters. Each code reflects some social, literary and cultural aspects. We have grouped these codes into different categories such as honorific titles and terms of respect, references to customs and traditions, and greetings and conversational expressions.

\section{Honorific Titles and Terms of Respect}

Honorific titles or terms of respect are expressions used to evince admiration for the elderly, the educated and relatives. Dabbagh uses some honorific titles such as Sheikh (the leader of an Arab village or family), mukhtar (village chief) and mualima (a female teacher). She also employs code-switch-ing for titles of respect such as $\mathrm{Ya}$ akhi (my brother), Ammo (paternal uncle), Ya hajji (an old person), $A b u$ (the father of someone), Umm (the mother of someone), and jiddo (grand-father). These expressions which reflect Arab cultures de-note the behavior of the individuals towards the elderly and people of distinction. Examples of code-switching in the novel are many such as: "They gave him the reverence of a pilgrim (Ya hajji! Ya hajji!)" (ch.7, p.47);"Was that Hajjar?" "I think so. Yes. Sorry yaakhi, brother" (ch.5, p.23).Other examples on honorific titles and terms of respect include: "Strung him up in the village like a sheep. Big, portly man. He was not the mukhtar, the leader, but he was not far off" (ch. 19, p. 130); "Are you alright now Ammo?" (ch. 7, p. 48). The transliterated word Ammo does not refer to paternal or maternal uncle, but it is an honorific term which is not used in the English culture.

\section{References to Customs and Traditions}

Dabbagh is a bilingual and a bicultural author who depicts some aspects of Palestinian culture through the employment of code-switching. Out of It is rich with Palestinian codes that demonstrate the nature of some Palestinian customs and traditions including food, dress, forms of entertainment and references to religious culture.

\section{Food}

Food is an important aspect of traditions, distinguishing one culture from another one. For example, Indians are known for their spicy food. In Arab culture,there are a lot of proverbial references to food such as la tquul fuul layṣeer bilmakyuul (do not say bean until it ripens) which means do not count your chickens before they are hatched. Indeed, Selma's novel is full of switched codes relating to food. For example, the novel is riddled with references to types of food such astabouleh (a type of salad), zaatar (thyme), arak (wine), maamoul (a type of dessert), bizer (seeds) and bamya (okra).In chapter 46, Dabbagh says, "over a plate of bamya and rice in the kitchen, Rashid discovered that Khalil had brilliantly discovered two heroes in one afternoon" (p.287). In chapter 43, she says, "Khalil opened the palm of his hand, removed the remains of the maamoul that he had mashed into it, placed them on a saucer and walked out of the room" (p. 271). Dabbagh also states, "His mother mainly left the cooking to Sabri who could spend hours chopping parsley for tabouleh" (ch. 5, p. 31). Tabouleh derived from the Ar-abic word tabil (to spice) is an Arab dish that is not tied to one particular Arab region. By leaving the word tabouleh untranslated, Dabbagh forces monolingual readers to search for the meaning of this word.

\section{Dress}

The different types of dress mentioned in this novel are of old types that have become a part of the Palestinian heritage. For instance, in the novel, I have thoub (a long dress for women), mandil (head scarf), abaya (a loose black or brown robe from head to toe, traditionally worn by women and men), dishdasha (a white long one piece tunic worn by Arab men)and keffiyeh (an Arab headdress consisting of a square piece of cloth folded into a triangle and fastened over the crown by an agal). It could be argued that Dabbagh intention-ally code-switched these types of clothes in order to promote the reader to search for the meaning of these types and hence get to know the Palestinian traditions closely. The examples of dress switched codes are plenty and some of them are re-peated over the course of the novel. For instance, Dabbagh repeats the code thoub in different places. She iterates it in chapters 4, 5, and 49: "there was so much stuffed into the internal chest pocket of her thoub" (p. 22); "She was wear-ing her long, sloppingaround-the-house thoub" (p. 31); "She could not run in her mother's thoub" (p. 296). Dabbagh used the Arabic term to distinguish the item of clothing as there isno English equivalent for thoub.

\section{Forms of Entertainment}

These forms include argeela (shisha), dabka (a form of dance especially at weddings) and argeela (storytellers). Palestinians use these forms so as to escape the harsh re-ality brought about by Israeli occupation. This is clear in Dabbagh's saying that "they appeared to talk to each oth-er like old men resting against cushions smoking argeela" (ch.6, p.37); "The audience had been rapt. Each line had been followed up by commentary from the coffee-drinking, arg-eela-smoking gathering" (ch.12, p.80). Other examples in-clude: "Wherever he could, he found cafes to take her where argeela, storytellers, recounted tales passed down from gen- 
eration to generation" (ch. 12, p. 80); “They had asked for something simple, old-fashioned: a dress with embroidery, hennaed hands, and a troop of men dancing the dabke" (ch. 12, p. 81).Storytelling and dabke which reinforce the discourse of cultural resistance against narratives of oblivion and forgetfulness suggests the author's cultural and national belonging. Apart from being a means of pedagogy and entertainment, storytelling and dabke strengthen Palestinian, communal bonds and ensure the survival of Palestinian traditions which articulate Palestinian social, political identity that Israeli occupation strives to obliterate and falsify to justify and legitimise their claim on Palestine.

\section{Religious Traditions}

There are some codes in the novel that relate to religious concepts and traditions such as muezzin (one who calls for prayer from the minaret of the mosque), Ramadan (the ninth month of the Islamic calendar; the month of fasting), muhajabat (veiled women), and Ibn Shaheed (the son of a martyr). These codes are associated with national and religious aspects of Palestinian culture. For example, muezzin and muha-jabat refer to prayer. Dabbagh says that "Prayer, the muezzin cajoled, is better than sleep" (ch. 2, p. 11). She tells the read-er that "So, the pretty... there was even a belly dancer, and there were quite a lot of muhajabat, you know, veiled women" (ch. 20 , p. 140).In addition, Ramadan refers to the holy month of fasting, and Ibn Shaheedis a part of the Palestinian national discourse. The title given to the fathers and mothers of martyrs, Ibn Shahid and Um Shahid is a sign of honour and respect. Dabbagh says that "He didn't have to do anything. His parents are assassinated, weren't they? Ibn Shaheed, the son of martyrs and all of that" (ch. 25, p. 172).

\section{Greetings and Conversational Forms}

This category of code-switching includes: sah (right), aadi(normal), bisser(it happens), bilaks (on the contrary), mubrook (congratulations), bikafee (enough), tsharafna (an honor),yazalame (comrade), mishta' habibi (I am missing you, my dear), malik ya habibti (what's wrong honey?), khalas(enough), yukhrub baithum awlad ars(goddamn their houses, those sons of pimps),akheeran (finally), shabab (guys), yallah (come on), Aaah (yes), shuuf sho helou (look how nice), Aanjad (seriously), hayk (like this), fahemkeef? (you see how it is?) and batal (a hero). These simple and common everyday used forms highly represent the simplicity of the Palestinian culture. Dabbagh devotes a large area in her novel to these expressions since they denote the inter-relatedness between language and culture; language is the mouthpiece of culture. For example, Selma says, “'Shuuf! Shohelou!' Look how nice, the boy said as he took the shoes out... 'try them if you want', Rashid offered. Aanjad? Seriously?" (ch.42, p.268).These forms are used to express amazement and offer respectively. Moreover, the following form is used for requests, "It was not until Cairo Airport where a cleaning lady had asked if she was OK, "Malik yahabibti? Salamtik ya habibti'" (ch.23, p.156). Other expressions are used to express congratulations: "'Got what?"
Khalil asked. 'The scholarship'. Rashid's hands opened up, what else? 'For London'. 'Well done', Khalil said. "Congratulations. Mubrook"' (ch. 9, p. 62). Dabbagh employs expressions of swearing and insulting which are parts of the Palestinian common sayings: "No of course not. Damn it. It's just the situation. Yukhrub bait'hum, awlad ars, goddamn their houses, those sons of pimps" (ch. 25 , p. 167). In addition to the above mentioned expressions of amazement, insult and swearing, Dabbagh employs Palestinian expressions of welcome and hospitality which are intrinsic parts of Palestinian culture: "Again, we would like to stress that we are sorry for the disturbance. Tsharafna. It was honor to have met" (ch. 15, p. 101).

\section{Geographic Areas}

Swisra (Switzerland),Tunis(Tunisia) and Albahr al abyad (the Mediterranean) are names of geographical areas that went under switching in Selma's novel: "Flip, flip, flip for he doesn't fly, he is flipping now over the sea, the White Sea, al bahr al abyad, the Mediterranean" (ch. 1, p. 5); "Swisra, someone was saying behind her, Switzerland" (ch. 2, p. 6).

All these categories which were code-switched exemplify the various aspects of the Palestinian culture.

\section{Cultural and Textual Hybridity}

Dabbagh's Out of It is a text of cultural hybridity with characters who have hybridized selves that are influenced by cultural exchanges between Arab-Palestinian and British cultures. The word "hybrid" refers to something of a mixed character made by mingling two different elements. One of the most remarkable aspects of Selma's novel is the hybridity of the text and culture. Bakhtin (1981) points out that literature includes an array of forms and registers within language, a feature that he refers to as heteroglossia which is intrinsic to the genre of the novel: "The novel can be defined as a diversity of social speech types (sometimes even diversity of languages) and a diversity of individual voices, artistically organized" (p. 262). In the light of Bakhtin's doctrine of heteroglossia, the inclusion of more than one language is a natural artistic development of the novel. Textual hybridity refers to the combination of two cultures in one text; the novel's hybridity appears in the way it uses "cultural references; hybrid texts are produced by writers who want to highlight their position between cultures, creating a new site of individual and collective expression" (Simon, 2001: 217218).Out of It is a novel that does not only employ various cultural references such as fellahin (peasants), madrasa (a school), or shekels (the Pales-tinian currency), but it also gives the main characters Arabic names such as Rashid, Iman, Sabri, Mujahid, Khalil, etc. In her comment on the names she employed in the novel, Dabbagh says that "Rashid was a name I picked due to its connection with Arab heroism e.g. Harun al Rashid". She wrote that she chose the name Sabri "because there was an idea of being rooted, connected in the way that Sabra is" (personal communication, February 2, 2018). The events of the novel, the setting, and the way of life depicted in the Palestinian society necessitate the usage of Arabic names. For example, in the 
novel, Iman says that "I'm not going to run off, but you can't hold me like this. Stop it. Bikafee. Enough!" (ch. 13, p. 87).If the main character is not named an Arabic name, "Iman", Dabbagh wouldn't be able to code-switch "enough" into bikafee.

Cultural hybridity creates an identity for Out of It. Bhabha (1994) says that the "interstitial passage between fixed identifications opens up the possibility of a cultural hybridity" (p.4). Dabbagh tries to innovate a new identity for her text through the investment of code-switching for some terms. In cultural studies, hybridity entails "multiple identities, crossover, pick-'n'-mix, boundary-crossing experiences and styles, matching a world of growing migration and di-aspora lives, intensive intercultural communication, every-day multiculturalism and erosion of boundaries" (Pieterse, 2001, p. 3). The phrase "Arablish" refers to the combination of Arabic and English in the same text, thus, bringing two cultures together. The novel is an embodiment of the Pales-tinian reality, society, and diversity within the boundaries of a foreign frame (English language).The results and effects of interaction with other cultures would not be restricted to the change in characters' behavior, thoughts, or ways of life, but it will affect the motifs of writing that will lead to the production of a hybrid text.

\section{CONCLUSION}

By her extensive and intensive use of code-switching which is defined as the alternation from one language into another, Dabbagh establishes herself as a postcolonial author who has come up with indigenous cultural assertiveness by the deft use of language. She uses English as a medium of writing, yet she attempts to enrich English language with linguistic items from Palestinian culture, making it more Arabicized to carry the cultural experiences of Palestinian society. She domesticates the English language in her novel, using it so as to globalize Palestinian culture, traditions and heritage. We have pointed out that this technique of code-switching is used by bilinguals for several reasons; either to compensate deficiency in a language, to communicate literary, social, and cultural effects or to express solidarity with Palestinian cause and culture. We gathered the different switched codes in categories such as honorific titles and terms of respect, references to customs and traditions, greeting and conversational formulas, and geographic areas. We have pointed out that Dabbagh's employment of code-switching in the novel creates what is referred to as textual and cultural hybridity. The mingling of two languages leads to the mingling of two cultures in the same text.

\section{REFERENCES}

Ashcroft, B. et al. (2002). The Empire Writes Back. Theory and Practice in Post-Colonial Literatures. London: Routledge.

Auer, P. (1995). The Pragmatics of Code-Switching: A Sequential Approach. Cambridge: Cambridge University Press.

Bakhtin, M. (1981). The Dialogic Imagination: Four Essays. Trans. Caryl Emerson and Michael Holquist. Austin: U of Texas.

Bhabha, H. (1994). The Location of Culture. London: Rout-ledge.

British Council (2017): Selma Dabbagh; Fiction, Graphic, Novels and illustration. Retrieved from https://literature.britishcouncil.org/writer/selma-dabbagh (accessed: 2 October 2017).

Crystal, D. (1987/1994). The Cambridge Encyclopedia of Language. Cambridge: Cambridge University Press.

Dabbagh, S. [bqfpublishing]. (2012, July 9). Selma Dabbagh on CNN. Retrieved from https://www.youtube.com/ watch?v=Lx_ScugRr68 (accessed: 17 October 2017).

Ervin- Tripp, S. M. (1964). An Analysis of the Interaction of Language, Topic and Listener. Stanford: Stanford Uni-versity Press.

Martin, H. (2005). Code-switching in US Ethnic Literature: Multiple Perspectives Presented Through Multiple Languages. Appalachian State University, 12(3), 403-415.

Monica, H. (1988).Codeswitching: Anthropological and sociolinguistic perspectives (Contributions to the Sociology of Language 48). Berlin: Mouton de Gruyter, 19(3), 278.

Moore, L. (2015). [A Conversation with Selma Dabbagh]. Journal of Postcolonial Writing, 51(3), 324-339.

Omole, J. (1998). Code-switching in Soyinka's The Interpreters. In: Edmund L.

Epstein \& Robert Kole (eds.), The Language of African Literature. Trenton:

Africa World Press Inc, 57-72.

Pieterse, N. (2001). Hybridity, So What? The Antihybridity Backlash and the Riddles of Recognition. Theory, Cul-ture \& Society. 18(2-3), 3.

Simon, Sh. (2001). Cultural and Textual Hybridity. Across languages and cultures, 2(2), 217-226.

Skiba, R. (1997). Code Switching as a Countenance of Lan-guage Interference. The Internet TESL Journal, $3(10)$. 